\title{
ANABOLIC STEROID ABUSE AND PANCREATIC INSULINOMA
}

\author{
NADUŻYWANIE STERYDÓW ANABOLICZNYCH \\ PROWADZĄCE DO ROZWOJU GUZA INSULINOWEGO TRZUSTKI
}

\author{
Department of General and Transplant Surgery, Medical University of Lodz, \\ Norbert Barlicki Memorial Teaching Hospital, Lodz, Poland
}

\begin{abstract}
Su m m a r y
B ackground. Anabolic steroid abuse is very common among bodybuilders and is related with a number of medical complications including tumorgenesis.

Cas e report. A 29-year-old male bodybuilder with one year history of abusing large doses of anabolic steroids presented with several episodes of neuroglycopenia with concomitant loss of consciousness. Results of imaging studies (USG, MRI, EUS) showed smooth-demarcated, focal solid lesion of $2 \mathrm{~cm}$ in diameter in the body of the pancreas. The patient was characterized by Whipple's triad (hyperinsulinemia accompanied by hypoglycemia and signs of symptoms resolving upon glucose administration). No other disturbances were observed. The patient was qualified

for the surgical treatment. Intraoperatively, tumor enucleation was performed. Postoperative time was complicated by pancreatic fistula that required reoperation involving Roux pancreaticojejunostomy. The pathological examination revealed encapsulated benign neuroendocrine tumor. The patient has been followed up for 3 years and remained disease free.

Conclusion. Given the widespread use anabolic steroids among bodybuilder, another potentially lifethreatening tumor is highlighted. Insulinoma has not been previously reported in athletes. Bodybuilders should be aware of the serious medical risks including neuroendocrine tumors.
\end{abstract}

\section{Streszczenie}

W prowadzenie. Nadużywanie steroidów anabolicznych jest częste wśród kulturystów. Powiązane jest to $\mathrm{z}$ wieloma negatywnymi skutkami zdrowotnymi - w tym $\mathrm{z}$ rozwojem nowotworów.

Op is przypadku. 29-letni kulturysta z rocznym przyjmowaniem dużych dawek steroidów anabolicznych w wywiadzie zaprezentował kilka epizodów neuroglikopenii z towarzyszącymi utratami przytomności. Wyniki badań obrazowych (USG, MRI, EUS) ujawniły lite ognisko o dość wyraźnych granicach i średnicy $2 \mathrm{~cm} \mathrm{w}$ trzonie trzustki. Objawy pacjenta układały się w obraz triady Whipple'a (hiperinsulinemia $\mathrm{z}$ towarzyszącą hipoglikemią oraz ustępowanie objawów po podaniu glukozy). Innych odchyleń od normy nie zaobserwowano. Pacjent został zakwalifikowany do leczenia chirurgicznego - przeprowadzono zabieg wyłuszczenia guza trzustki. Przebieg pooperacyjny był powikłany wystąpieniem przetoki trzustkowej, wymagającej reoperacji z zespoleniem trzustkowo-jelitowym sposobem Roux. Badanie histopatologiczne wykazało obecność otorebkowanego łagodnego guza neuroendokrynnego. Pacjent był poddany obserwacji przez 3 lata, w tym czasie nie zaobserwowano nawrotu choroby.

W n i oski. Biorąc pod uwagę częste zjawisko zażywania sterydów anabolicznych przez kulturystów, niniejsza praca zwraca uwagę na możliwość wtórnego rozwoju kolejnego, potencjalnie zagrażającego życiu nowotworu. Guz insulinowy nie był poprzednio opisywany u sportowców. Kulturyści powinni być świadomi pewnych następstw zdrowotnych w związku z zażywaniem steroidów anabolicznych.

Key words: insulinoma, anabolic steroids, bodybuilder

Stowa kluczowe: guz insulinowy, steroidy anaboliczne, kulturyści 



\section{INTRODUCTION}

Anabolic steroid abuse is very common among bodybuilders, in order to increase muscle mass and strength, which may result in better sports achievements. However, it is related with a number of medical complications including cardiomyopathy, renal failure, jaundice and, finally, tumorigenesis [1]. There have been reported different types of tumors in athletes, although insulinoma development has previously not been described. Insulinoma is the most common neuroendocrine pancreatic tumor, still it is an extremely rare finding. The incidence is estimated at 1-3 per million per year. Pathogenesis of this tumor is not fully understood although its occurrence is known in MEN-1 syndrome [2]. To our knowledge, there is no research about insulinoma development dependent on anabolic steroids conducted. However, pancreatic adenocarcinoma growth stimulated by the androgen testosterone has been demonstrated [3].

We present the first case worldwide of insulinoma growth in a bodybuilder.

\section{CASE PRESENTATION}

A 29-year-old male bodybuilder was admitted to the Department of General and Transplant Surgery with several episodes of neuroglycopenia with concomitant loss of consciousness over the past 8 months. The patient was characterized by Whipple's triad (hyperinsulinemia accompanied by hypoglycemia and signs of symptoms resolving upon glucose administration). No other disturbances were observed. Moreover, the patient had one year history of abusing large doses of anabolic steroids; however, denied smoking and illicit drug use.

The patient underwent 72-hour fast, which had to be stopped in $35^{\text {th }}$ hour, due to the symptoms of neuroglycopenia. The obtained blood glucose level was $1.7 \mathrm{mmol} / \mathrm{L}(3.38-5.55 \mathrm{mmol} / \mathrm{L})$ with concurrent insulin $18.4 \mu \mathrm{U} / \mathrm{ml}(6-24 \mu \mathrm{U} / \mathrm{ml})$. These results hypoglycemia and lack of insulin suppression - are characteristic for insulinoma.

Results of imaging studies (USG, MRI, EUS) showed smooth-demarcated, focal solid lesion of $2 \mathrm{~cm}$ in diameter in the body of the pancreas (Figure 1). No other disturbances of abdominal organs were observed. The patient was in good physical condition, systemic examination and past medical history were unremarkable.

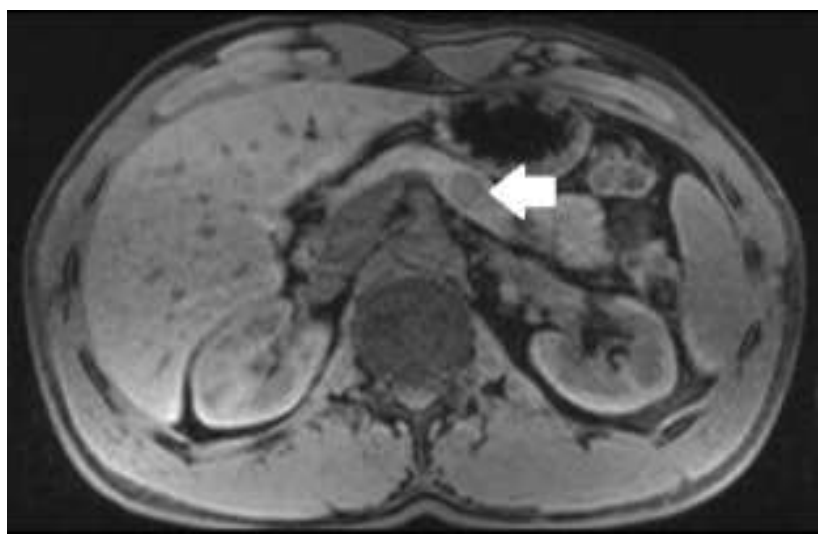

Fig. 1. Tumor of the body of the pancreas (arrow), MRI Rys. 1. Guz trzonu trzustki (strzałka), RM

Laboratory studies showed significant elevation of pancreatic enzymes: amylase was more than two times, and lipase almost four times above the upper limit of normal. Liver and kidney function tests were normal, along with neoplasmatic markers within normal limits.

The patient was qualified for the open surgical treatment. Intraoperatively, existence of encapsulated pancreatic tumor was confirmed and its enucleation was performed. The convalescence was uneventful and the patient was discharged on the $8^{\text {th }}$ postoperative day.

However, two weeks after the surgery, the patient was admitted to the same department because of an abdominal pain. The ultrasound revealed the presence of pancreatic fistula; therefore, the ultrasound-guided puncture and the endoscopic papillotomy were conducted. Despite the treatment, the leakage from a drain continued and for that reason the patient required reoperation involving Roux-en-Y pancreatojejunostomy. After the surgery, the patient's condition was gradually improving and further hospitalization was uneventful.

The pathological examination revealed encapsulated benign neuroendocrine tumor. The patient has been followed up for 3 years and remained disease free.

\section{DISCUSSION}

Insulinomas are very rare, mostly welldifferentiated and benign endocrine tumors. In 90\% they tend to appear as solitary intrapancreatic lesions, often $\leq 2 \mathrm{~cm}$ at presentation. However, they can be associated with multiple endocrine neoplasia type 1 and those tumors tend to be multiple, malignant and extrapancreatic [4]. Main symptoms are those connected with neuroglycopenia (for instance 
dizziness, headache, blurred vision and confusion) and manifestations from autonomic nervous system (like sweating, weakness, nausea, tremor, anxiety). The most characteristic condition for insulinoma is the Whipple's triad: symptoms of hypoglycemia resolving upon glucose administration and decreased plasma glucose level $(\leq 40 \mathrm{mg} / \mathrm{dl})$ [2]. The gold standard in diagnosis of inulinoma is the 72-hour fast, which reveals failure of appropriate insulin suppression in the presence of hypoglycemia.

Treatment of choice is surgical excision, which includes tumor enucleation or pancreatic resection. This procedure allows pathologist to confirm the completeness of excision and the benign character of insulinoma. Blind distal pancreatectomy is not recommended anymore, due to the fact that most of non-palpable small lesions tend to appear in the pancreatic head [5].

Anabolic steroids are commonly used by bodybuilders to enhance their sport achievements, due to their ability to increase muscle mass and strength, decrease recovery time and promote healing of injuries [1]. However, they are known to have many adverse effects, for instance cardiomyopathy, myocardial infarction, hypogonadism, hepatic dysfunction [6] and, finally, tumorigenesis.

Development of many tumors has been associated with anabolic steroid abuse, like hepatic adenoma [7] and adenocarcinoma [8] - which are the most frequently reported neoplasms, ganglioneuroma [9] and Wilms' tumor [10].

In most instances, the tumorigenesis was preceded by a long-term intake of anabolic steroids. However, even 2 years of anabolic steroid use may lead to tumorigenesis [8]. That is why, time of anabolic androgenic steroids (AAS) abuse is not the determinant of the risk of tumor development. Besides, the tumorigenesis after steroid withdrawal may also occur. A weightlifter developed an intratesticular leiomyosarcoma 9 years after he stopped AAS doping [11].

Moreover, recidivistic steroid abuse can contribute to the tumor regrowth [12], which indicates the role of steroids in tumorigenesis. This fact points out that after diagnosis, the steroid intake must not be continued.

Multiple hepatocellular carcinomas' growth in a bodybuilder has also been described, who, besides at least 20 lesions in the liver, developed chronic kidney disease and coronary artery disease. In consequence of the advanced process, the patient was given transarterial embolization [11]. According to Martin et al., growth of multiple hepatic adenomas could be linked to the use of AAS. The surgical management was conducted; however, it did not manage to remove all the tumors. After the withdrawal of drug administration, the adenomas spontaneously reduced their size [12]. Nevertheless, the radical surgical treatment seems to be the gold standard in management of AAS-induced tumors, due to their possible malignant transformation. It has been described that hepatocellular carcinoma raised from hepatic adenoma, which growth was associated with steroid intake [8]. Furthermore, another important issue is the coexistence of both malignant and benignbenign neoplasm [14], which entails the need of radical treatment even benign lesions.

Interesting issue is the development of steroiddependent tumor after treatment of aplastic anemia. There are described cases of hepatocellular carcinoma [15] and littoral cell angioma of the spleen [16] after 3 years of steroid therapy.

According to Sved et al., who described a fast beginning and enlargement of multiple angiolipomas in a patient with familial angiolipomatosis, the rapid onset or growth of those tumors may be a sign of steroid abuse [17].

Nevertheless, development of anabolic steroiddependent tumors is mostly not understood. In pancreatic tissue, as well as in pancreatic adenocarcinoma, anabolic receptors have been detected [18]. As reported by Okitsu et al., those receptors may play an important role in carcinogenesis in pancreas, because the androgen receptor mediated transcription occurs in pancreatic cancer cell lines [19]. There has been a study of the effect of hormone therapy on the growth of human non-endocrine pancreatic adenocarcinoma xenografts in nude mice conducted, which indicated that the androgen testosterone stimulated tumor growth rate [3].

\section{CONCLUSIONS}

To sum up, this is the first reported case of insulinoma growth in a bodybuilder, which is another potentially life-threatening adverse effect of anabolic steroid abuse. It indicates the necessity of introducing screening procedures in this certain group. Furthermore, patients with diagnosed tumor have to undergo radical surgical treatment and meticulous postoperative supervision. 
Bodybuilders should be aware of the serious medical risks including neuroendocrine tumors.

\section{REFERENCES}

1. Maravelias C, Dona A, Stefanidou M, et al. Adverse effects of anabolic steroids in athletes. A constant threat. Toxicology Letters, 2005; 158: 167-175.

2. de Herder WW, Niederle B, Scoazec JY, et al. Well differentiated pancreatic tumor/carcinoma: insulinoma. Neuroendocrinology, 2006; 84: 183-8.

3. Greenway BA, Duke D, Pym B, et al. The control of human pancreatic adenocarcinoma xenografts in nude mice by hormone therapy. British Journal of Surgery, 1982; 69: 595-597.

4. Varma V, Tariciotti L, Coldham C, et al. Preoperative localisation and surgical management of insulinoma: single centre experience. Digestive surgery, 2011; 28: 63-73.

5. Tucker ON, Crotty PL, Conlon KC. The management of insulinoma. The British Journal of Surgery, 2006; 93(3): 264-275.

6. Birzniece V. Doping in sport: effects, harm and misconceptions. Internal Medicine Journal, 2015; 45(3): 239-248.

7. Socas L, Zumbado M, Pérez-Luzardo $O$, et al. Hepatocellular adenomas associated with anabolic androgenic steroid abuse in bodybuilders: a report of two cases and a review of the literature, British Journal of Sports Medicine, 2005; 39(5): e27.

8. Gorayski P, Thompson $\mathrm{CH}$, Subhash $\mathrm{HS}$, et al. Hepatocellular carcinoma associated with recreational anabolic steroid use. British Journal of Sports Medicine, 2008; 42: 74-75.

9. Durczyński A, Sporny S, Szymański D, et al. Retroperitoneal ganglioneuroma in a young bodybuilder, Clinical and Experimental Medical Letters, 2010; 51(2): 155-157.

10. Prat J, Gray GF, Stolley PD, et al. Wilms Tumor in an Adult Associated With Androgen Abuse. JAMA, 1977; 237(21): 2322-2323.

11. Froehner M, Fischer R, Leike S, et al. Intratesticular leiomyosarcoma in a young man after high dose doping with Oral-Turinabol: a case report. Cancer, 1999; 86(8): 1571-5.
12. Martin NM, Abu Dayyeh BK, Chung RT. Anabolic steroid abuse causing recurrent hepatic adenomas and hemorrhage. World J Gastroenterol, 2008; 14(28): 4573 4575.

13. Kesler T, Sandhu R, Krishnamoorthy S. Hepatology: hepatocellular carcinoma in a young man secondary to androgenic anabolic steroid abuse. Journal of Gastroenterology and Hepatology, 2014; 29(11): 1852.

14. Solbach P, Potthoff A, Raatschen H-J, et al Testosterone-receptor positive hepatocellular carcinoma in a 29-year old bodybuilder with a history of anabolic androgenic steroid abuse: a case report. BMC Gastroenterology, 2015; 15(1): 60

15. Kosaka A, Takahashi H, Yajima Y, et al. Hepatocellular carcinoma associated with anabolic steroid therapy: report of a case and review of the Japanese literature. Journal of Gastroenterology 1996; 31(3): 450-4.

16. Tholouli E, Roulson JA, Byers R, et al. Littoral cell angioma of the spleen in a patient with severe aplastic anaemia. Haematologica, 2003; 88(11): ECR33.

17. Syed SP, Brooks DG, Haupt HM, et al. Anabolic steroids causing growth of benign tumors: androgen receptor in angiolipomas. Journal of the American Academy of Dermatology, 2007; 57(5): 899-900.

18. Corbishley TP, Iqbal MJ, Wilkinson ML, et al. Androgen receptor in human normal and malignant pancreatic tissue and cell lines. Cancer, 1986; 57: 1992-1995.

19. Okitsu K, Kanda T, Imazeki F, et al. Involvement of interleukin-6 and androgen receptor signaling in pancreatic cancer. Genes Cancer, 2010; 1: 859-867.

\section{Address for correspondence:}

Aleksandra Oleśna

Department of General and Transplant Surgery

Medical University of Lodz

Norbert Barlicki Memorial Teaching Hospital

Kopcinskiego Street 22

90-153 Lodz, Poland

e-mail: a.olesna@gmail.com

phone number: 426776755

Received: 30.03.2016

Accepted for publication: 30.06.2016 